\title{
Factors associated with poor outcome in right heart endocarditis
}

\author{
Mihaela Lavinia Zamfiraa ${ }^{1,2^{*}}$, Șerban Benea ${ }^{1,2}$, Cozmina Andrei ${ }^{1}$, Georgeta Ducu', Daniela Camburu', Mihaela Ionică' \\ Alina Cozma ${ }^{1}$, Roxana Dumitriu', Otilia Elisabeta Benea ${ }^{1,2}$ \\ From The 9th Edition of the Scientific Days of the National Institute for Infectious Diseases Prof Dr Matei \\ Bals \\ Bucharest, Romania. 23-25 October 2013
}

\section{Backgroud}

We studied factors associated with poor outcome in right heart endocarditis.

\section{Methods}

In the period January 2011 - December 2012 at the National Institute for Infectious Diseases "Prof. Dr. Matei Balş" were admitted 53 patients with right endocarditis, with 72 episodes.

\section{Results}

Males predominated (64.2\%), patients in the age group 20 -39 years $(83 \%)$, those from urban areas $(81 \%)$ and unemployed persons (69.8\%). The infection was localized to the tricuspid valves -42 cases, tricuspid valves plus left heart -6 cases, right atrial wall -3 cases, pulmonary valve -1 case, right atrial device -1 case. The main risk factor for right endocarditis was as IV drug use (86.8\%). $87 \%$ of patients had HCV infection and $52.2 \%$ were HIV infected. Blood cultures were positive in $73.6 \%$ of cases. Staphylococcus aureus was the most frequently isolated (73.7\%), type MSSA in $51.3 \%$ of cases.

Under treatment with antibiotics, anticoagulants, diuretics evolution was towards improvement in 52.8\% of cases and $18.9 \%$ for death.

Factors associated with risk of poor outcome were: the presence of tricuspid murmurs (from $8 / 10$ deaths vs. $13 / 43$ survivors, $\mathrm{p}=0.003$; OR $=9.231,95 \% \mathrm{CI}: 1.719$ 49.55), the occurrence of embolic complications (4/10 deaths vs. $5 / 43$ survivors, $\mathrm{p}=0.03$; $\mathrm{OR}=5.067,95 \% \mathrm{CI}$ : 1.052 24.39), the presence of multiple pulmonary microabscesses

\footnotetext{
* Correspondence: mihaelazamfira@yahoo.com

1National Institute for Infectious Diseases "Prof. Dr. Matei Balş", Bucharest, Romania
}

Full list of author information is available at the end of the article
( $8 / 10$ patients vs. $14 / 43, \mathrm{p}=0.004$; OR=8.286, $95 \%$ CI: 1.551 44.26), tricuspid vegetations larger than $10 \mathrm{~mm}(7 / 10$ deaths vs. $5 / 43$ survivors, $\mathrm{p}=0.0002$; $\mathrm{OR}=17.73,95 \% \mathrm{CI}$ : 3.431-91.66), the association of HIV infection with elevated HIV-RNA and severe immune deficiency with CD4 below 200 cells $/ \mathrm{cmm}$.

\section{Authors' details}

"National Institute for Infectious Diseases "Prof. Dr. Matei Balş", Bucharest, Romania. ${ }^{2}$ Carol Davila University of Medicine and Pharmacy, Bucharest, Romania.

Published: 16 December 2013

doi:10.1186/1471-2334-13-S1-P108

Cite this article as: Zamfira et al:: Factors associated with poor outcome in right heart endocarditis. BMC Infectious Diseases 2013 13(Suppl 1):P108.
Submit your next manuscript to BioMed Central and take full advantage of:

- Convenient online submission

- Thorough peer review

- No space constraints or color figure charges

- Immediate publication on acceptance

- Inclusion in PubMed, CAS, Scopus and Google Scholar

- Research which is freely available for redistribution

Submit your manuscript at www.biomedcentral.com/submit
C Bïomed Central
C Biomed Central

(C) 2013 Zamfira et al; licensee BioMed Central Ltd. This is an Open Access article distributed under the terms of the Creative Commons Attribution License (http://creativecommons.org/licenses/by/2.0), which permits unrestricted use, distribution, and reproduction in any medium, provided the original work is properly cited. 